\title{
Strengthen Students' Character through Inquiry Based Termochemical I Experiment
}

\author{
O Sobandi \\ Prodi Pendidikan Agama Islam, Fakultas Tarbiyah dan \\ Keguruan \\ UIN Sunan Gunung Djati \\ Bandung, Indonesia \\ obansobandi@uinsgd.ac.id
}

\author{
S Sari \\ Prodi Pendidikan Kimia, Fakultas Tarbiyah dan Keguruan \\ UIN Sunan Gunung Djati \\ Bandung, Indonesia \\ sari@uinsgd.ac.id
}

\begin{abstract}
The 21st century skills needed is a quality of character, and basic literacy in order to realize the gold generation in 2045. Strengthening of the characters on all levels of education is to strengthen moral values, morality, and the personality of students by strengthening the character education integrated in all subjects. This study aims to describe the reinforcement of student character through thermochemical I experiment through inquiry based worksheet. The subjects were 20 students. Data were collected using observation sheets and student worksheets based on inquiry. Research results showed strengthening of the character of students through inquiry-based thermochemical I experiment performed in nine stages there were habituation to read verses from the Al Qur'an, implementation of the pre-test, pre laboratory, observation, manipulation or formulating problems, make hypotheses, verification, data analysis and make conclusions. Based on the steps taken, the expected strengthening of the characters are religious, love reading, honest, discipline, responsibility, curiosity, tolerance, hard work, friendly and appreciate achievement.
\end{abstract}

Keywords-based Inquiry; experiment; strengthening of character; thermochemistry I

\section{INTRODUCTION}

Efforts to strengthen character is higher than moral formation, because character formation is not only concerned with what is right or wrong, but how to instill habits about things that are good in life. Thus, learners have high awareness and understanding, as well as concern and commitment to implement the virtues in everyday life [1]. Pattern of character strengthening in each institution is different. This is due to different rules. Higher education as a culmination point of the formal education process has a role and responsibility in strengthening the character of the nation that has been built and developed since primary education.

Strengthening the character through the experiment is very likely to realize the character values [2]. Inquiry learning through the experiment in laboratory can instill student attitudes [3]. This is in line with one of the national educational goals that is faithful and cautious to God Almighty, have noble character, and responsible" [4].
Research on character development has been done by [5] that character can be formed through exemplary and habituation through learning process. In addition character can be formed through the learning process associated with daily life [6]. Character can be developed from a scientific-based practice [7]. In contrast with the researches, researchers put more emphasis on strengthening the character through inquiry based-worksheet on Thermochemical practice I.

\section{RESEARCH METHODS}

Descriptive research method was used to describe the process of conducting thermochemical I practice that is identification of instant heater and cooler pouch in reinforcing the character of students [8]. The sampling technique is using one group of practice which amounted to 20 students. The instrument used is an observation sheet that contains character enhancement that can be developed through the thermochemical I experiment and the inquiry-based student worksheet that contains the practice procedure on instant heater and cooler pouch. The instrument is processed by means of descriptions of characters that appear in each stage of inquiry, and then take percentage of occurrence of the characters on a scale of 100

Stages of research conducted on the basis of the stages of inquiry study were observation, manipulation, hypothesis, verification, data analysis and make conclusions [9]. The research procedure covered every student starts practice by first reading Al-Quran for 10 minutes, followed by pre-test on student ability in predict sample that can be used as material of instant heater and cooler, pre-test was done for 10 minutes. The lecturer gave pre-laboratory on the evaluation of preliminary journal that had been made by the students and the procedure of experiment to be performed as well as the character control. The experiment was done by using the Thermochemistry I worksheet on an inquiry-based instant heater and cooler pouch. After experiment the student returned the tools and materials that have been used. Then complete the post-laboratory followed by a discussion of the results of the experiment performed and prepared the practice report. Scheduled picket group have to clean laboratory. From the beginning to completion of experiment activities the character of students observed by five laboratory assistants. 


\section{RESULTS AND DISCUSSION}

The practice of each group is divided into four groups. Each group consists of four students. The experiment always begins by reading the Holy Qur'an for 10 minutes. The 20 students was reading together the verses Holy Qur'an led by one student. The lecturer always reminds students that Allah SWT will make the Qur'an a syafa'at to the people who always read it. This was expressed by the companions of $\mathrm{Abu}$ Umamah Al-Bahili radhiallahu 'anhu: I heard the Messenger of Allaah shalallahu 'alaihi wasallam said:

“Read by you the Qur'an. Because it (the Qur'an) will come on the Day of Judgment later as a giver of syafa'at for those who diligently reads it." [HR. Muslim 804] [10].

Habituation is done to provide motivation to students to always read the Qur'an. Do not let the Qur'an be forgotten from it because of their learning activities. So that religious characters appear on these 20 students.

After students read the holy verses of Al-Quran students followed the pre-test. The given pretest consists of two questions: "1. Explain the experimental principle of the experiment to be performed! 2. Predict which sample can be used as instant heater and cooler pouch? ". The average of the experimental principles of the experimental students to be conducted is to measure the temperature of the solution, mentions the definitions of exothermic and endothermic reactions, explains the experimental process, explaining the law of conservation of energy. And heat release and absorption.

The most pretest answers for number two is a sample used as an instant heater pouch that is Magnesium Sulfate and instant cooler is Ammonium Nitrate. There are five students who answer the instant cooler pouch is copper sulphate. The pretest aims to explore a preliminary understanding of students on concept that would be experimented. The characters that are expected to emerge from this stage are love to read and honest.

The next stage, the lecturer give pre-laboratory on the experimental principle of the experiment conducted that is the occurrence of release or absorption of heat. The uses of a thermometer at the time of temperature measurement is done by holding thermometer rope and inserting it into the calorimeter plug with the position of the thumb and forefinger holding the tip of the thermometer and then rotated it clockwise. If the thermometer is difficult to enter the calorimeter plug, then rinse the thermometer with water first, then the thermometer is rotated. Then read the thermometer with the eye position parallel to the thermometer. From this stage the expected characters are discipline and responsibility.

The next step the lecturer distributes the inquiry-based worksheets about the heater and instant cooler pouch. In stage of observation, it is given the discourse as shown in Figure 1. follows:

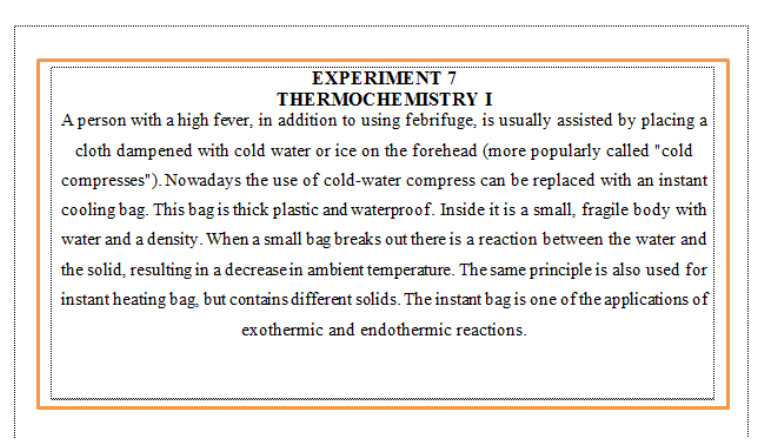

Fig. 1. Discourse on observation stage.

Based on the figure1 students are given information about the febrifuge compressing which is the application of exothermic and endothermic reactions. From the discourse, it will be obtained a clear description of the problem and instructions on how to solve it. So the character that can be formed from this observation stage is curiosity.

Stage of manipulation presented the question of making the problem formulation in accordance with the problems found in the discourse. The formulation of the problem created by the students is whether the reaction between water and the samples in the instant cooler and heater pouch requires energy or energy release. The character that can be formed from this stage is curiosity.

Stage of hypothesis students make a temporary answer based on the formulation of problems that have been made. The hypothesis of the experiments conducted by the students is the reaction between the water and the sample can release or require energy.

The stage of student identification makes the experimental procedure; following the student experiment result procedure can be seen in the following figure:

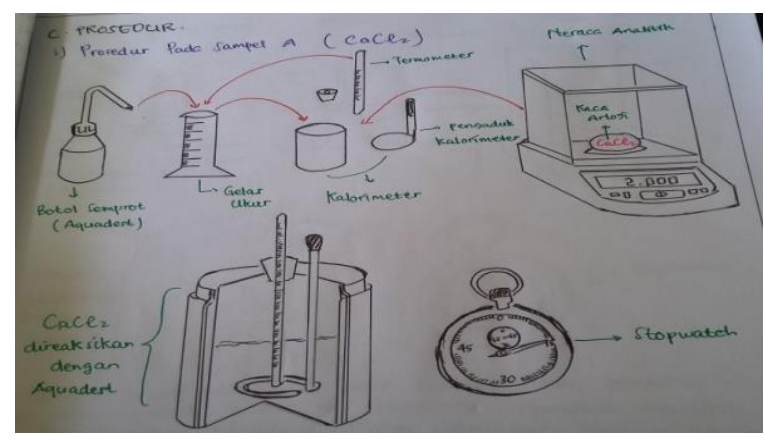

Fig. 2. Students' experiment procedures.

Based on the figure 2 students prepare the tools and materials to be used i.e. spray bottle, measuring cup, thermometer, scales, spatula, calorimeter, stopwatch, calcium chloride, ammonium nitrate, and calcium carbonate. Then the tools and materials they note on the log book of tools and materials. The function of the look book is to control the tools that will be returned by the student after the experiment. From this stage the expected character is responsibility and honest. 
The students' experimental processes are as follows: each sample is weighed two grams with analytic balance. The volume of aquades is measured as $15 \mathrm{~mL}$ by using a measuring cup. Then measure the initial temperature of the aquades with the thermometer. Then input the aquades and calcium chloride into the calorimeter, then stir, observe and record the temperature change every 30 seconds for five minutes. Do it for samples of ammonium nitrate and calcium carbonate. The characters expected from the stage of verification are responsibility, honest, tolerance, discipline, hard work and friendly.

Stage of data analysis done based on experiment procedure, so obtained by observation data based on table 1 below:

TABLE I. OBSERVATIONAL DATA

\begin{tabular}{|c|c|c|c|}
\hline No & material & Treatment & Observation \\
\hline \multirow[t]{5}{*}{1} & \multirow{5}{*}{$\begin{array}{l}\text { Samples A } \\
\text { Calcium } \\
\text { Chloride }\end{array}$} & $\begin{array}{l}\text { Calcium chloride } \\
\text { is weighed }\end{array}$ & Two grams \\
\hline & & $\begin{array}{ll}\text { The volume } & \text { of } \\
\text { aquades } & \text { is } \\
\text { measured } & \\
\end{array}$ & A total of $15 \mathrm{ml}$ \\
\hline & & $\begin{array}{l}\text { The initial } \\
\text { temperature of the } \\
\text { aquades is } \\
\text { measured }\end{array}$ & $\begin{array}{l}\text { The initial temperature of } \\
28^{\circ} \mathrm{C}\end{array}$ \\
\hline & & $\begin{array}{lr}\text { Aquades } & \text { are } \\
\text { reacted } & \text { with } \\
\text { calcium chloride } & \text { chide } \\
\text { in the calorimeter }\end{array}$ & $\begin{array}{l}\text { An increase in temperature } \\
\text { from } 28^{\circ} \mathrm{C} \text { to } 32^{\circ} \mathrm{C} \text { is done } \\
\text { per } 30 \text { seconds for } 5 \\
\text { minutes }\end{array}$ \\
\hline & & $\begin{array}{lr}\begin{array}{l}\text { Changes } \\
\text { occurred } \\
\text { observed }\end{array} & \text { were } \\
\end{array}$ & $\begin{array}{l}\text { Chloride diets are soluble } \\
\text { in water and include } \\
\text { exothermic reactions }\end{array}$ \\
\hline \multirow[t]{5}{*}{2} & \multirow{5}{*}{$\begin{array}{l}\text { Sample B } \\
\text { Ammonium } \\
\text { Nitrate }\end{array}$} & $\begin{array}{l}\text { Ammonium } \\
\text { Nitrate is weighed }\end{array}$ & Two grams \\
\hline & & $\begin{array}{ll}\text { The volume } & \text { of } \\
\text { aquades } & \text { is } \\
\text { measured } & \\
\end{array}$ & A total of $15 \mathrm{ml}$ \\
\hline & & $\begin{array}{lr}\text { The initial } \\
\text { temperature of the } \\
\text { aquades } \\
\text { measured }\end{array}$ & $\begin{array}{l}\text { The initial temperature of } \\
28^{\circ} \mathrm{C}\end{array}$ \\
\hline & & $\begin{array}{l}\text { Aquades are } \\
\text { reacted with } \\
\text { ammonium nitrate } \\
\text { in the calorimeter }\end{array}$ & $\begin{array}{l}\text { A temperature drop from } \\
28^{\circ} \mathrm{C} \text { to } 26^{\circ} \mathrm{C} \text { is } \\
\text { performed per } 30 \text { seconds } \\
\text { for } 5 \text { minutes }\end{array}$ \\
\hline & & $\begin{array}{l}\text { Changes that } \\
\text { occurred were } \\
\text { observed }\end{array}$ & $\begin{array}{l}\text { Ammonium nitrate is } \\
\text { soluble in water and } \\
\text { includes an endothermic } \\
\text { reaction }\end{array}$ \\
\hline \multirow[t]{5}{*}{3} & \multirow{5}{*}{$\begin{array}{l}\text { Sample C } \\
\text { Calcium } \\
\text { Carbonate }\end{array}$} & $\begin{array}{l}\text { Calcium carbonate } \\
\text { is weighed }\end{array}$ & Two grams \\
\hline & & $\begin{array}{ll}\text { The volume } & \text { of } \\
\text { aquades } & \text { is } \\
\text { measured } & \\
\end{array}$ & A total of $15 \mathrm{ml}$ \\
\hline & & $\begin{array}{l}\text { The initial } \\
\text { temperature of the } \\
\text { aquades } \\
\text { measured }\end{array}$ & $\begin{array}{l}\text { The initial temperature of } \\
28^{\circ} \mathrm{C}\end{array}$ \\
\hline & & $\begin{array}{lr}\text { Aquades } & \text { are } \\
\text { reacted with } \\
\text { Calcium carbonate } \\
\text { in the calorimeter }\end{array}$ & $\begin{array}{l}\text { An increase in temperature } \\
\text { from } 28^{\circ} \mathrm{C} \text { to } 29^{\circ} \mathrm{C} \text { is done } \\
\text { per } 30 \text { seconds for } 5 \\
\text { minutes }\end{array}$ \\
\hline & & $\begin{array}{l}\text { Changes } \\
\text { occurred } \\
\text { observed }\end{array}$ & $\begin{array}{l}\text { Occurs sediment and color } \\
\text { of white solution excluding } \\
\text { endothermic or exothermic } \\
\text { reactions }\end{array}$ \\
\hline
\end{tabular}

Graph of observation data of temperature change of sample A (calcium chloride) can be seen in Figure 3 below:

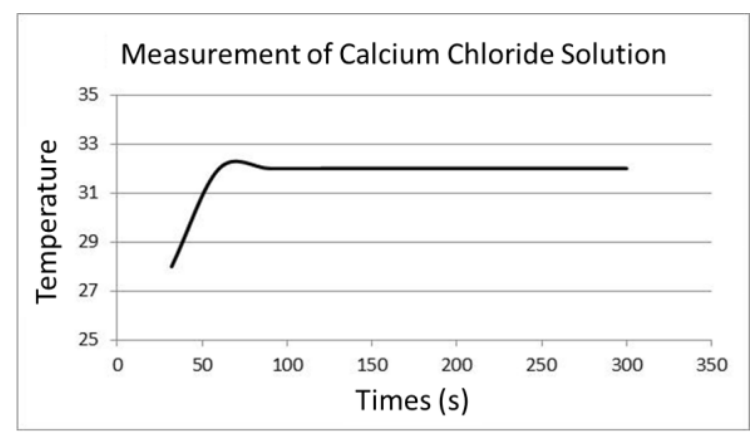

Fig. 3. Graph of calcium chloride temperature changes.

Based on the figure of 3 reactions between calcium chloride and water temperature rise, from the initial temperature of $28^{\circ} \mathrm{C}$ to $32^{\circ} \mathrm{C}$. This reaction includes exothermic reaction, the reaction that occurs when the release of heat. The calcium chloride is suitable for use as an instant heater pouch.

Graph of observation data of sample B that is Ammonium Nitrate can be seen in figure 4 below:

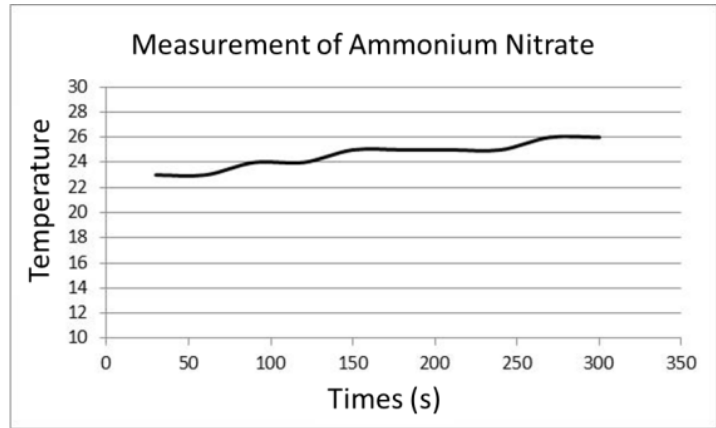

Fig. 4. Graph ammonium nitrate temperature changes.

Based on Figure 4 the reaction between ammonium nitrate with water to experience deterioration in temperature, from the initial temperature of $28^{\circ} \mathrm{C}$ to $26^{\circ} \mathrm{C}$ include endothermic reaction, the reaction that occurs when the ongoing heat absorption. Thus ammonium nitrate suitable for use as the instant cooler pouch.

Graph of observation data of sample $\mathrm{C}$ that is calcium carbonate can be seen in figure 5 below:

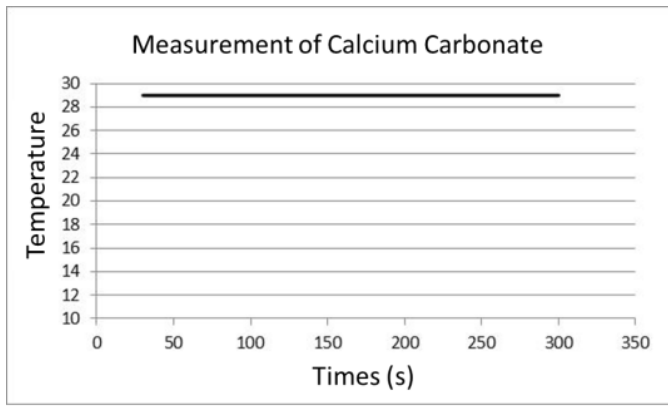

Fig. 5. Graph of changes in calcium carbonate temperature. 
Based on the figure of 5 reactions between calcium carbonate and water, the reaction will run very strongly and quickly when in powder form, calcium carbonate powder will release the heat. The molecule of $\mathrm{CaCO}_{3}$ will soon bind the water molecule $\left(\mathrm{H}_{2} \mathrm{O}\right)$ which will form calcium hydroxide, a soft substance such as a paste. As indicated in the reaction as follows: $\mathrm{CaCO}_{3}+\mathrm{H}_{2} \mathrm{O} \rightarrow \mathrm{Ca}(\mathrm{OH})_{2}+\mathrm{CO}_{2}$. Thus, calcium carbonate is not suitable as the instant cooler or heater pouch. Based on the data analysis stage, expected characters are honest, appreciate achievement and like to read.

The stages to make conclusions are based on data analysis. The conclusions made by the students based on the experiments carried out are materials suitable for use as instant heater filler is calcium chloride due to exothermic reaction and as the instant cooler filler is ammonium nitrate due to endothermic reaction.

\section{CONCLUSION}

Strengthening the character of students through the inquirybased thermochemical I practice is done in nine stages of reading the scripture Al-Qur'an, Implementation of pre-test, pre-laboratory, observation stage, manipulation or formulating the problem, making hypotheses, verification, data analysis and make conclusions. Based on the steps taken, the expected strengthening of the character is religious, reading, honest, discipline, responsibility, curiosity, tolerance, hard work, friendly and appreciate achievement.

\section{REFERENCES}

[1] Zubaedi, Desain Pendidikan Karakter (konsepsi dan aplikasinya dalam lembaga Pendidikan), Jakarta, Indonesia: Kencana prenada media group, 2011.

[2] Mitarlis, "Peran Kegiatan Praktikum Kimia Dasar I Materi Pemisahan," Jurusan Kimia FMIPA Unesa, 2012.

[3] E. Ural, "The Effect of Guided-Inquiry Laboratory Experiments on Science Education Students' Chemistry Laboratory Attitudes, Anxiety and Achievement," Journal of Education and Training Studies, pp. 217 $227,2016$.

[4] National Education Objectivesl, 2003.

[5] M.A. Rhamdhani, "Lingkungan Pendidikan dalam Implementasi Pendidikan Karakter," Jurnal Pendidikan Universitas Garut, pp. 28-37, 2014.

[6] M.A. Ramdhani, "Lingkungan Pendidikan Dalam Implementasi Pendidikan Karakter," Jurnal Pendidikan UNIGA, 2016.

[7] S.F.S.I.W.D.a.M. O Sobandi, "Application of the Scientific Approach to Develop Student Character," in international conference sosiology and education, Bandung, Indonesia, 2017.

[8] J. Willam Wiersma and Stephan G, Research Metodhs in Education in Introduction, Boston New York, 2009.

[9] C. Wenning, "The Levels of Inquiry Model of Science Teaching," J. Phys.Tchr. Educ, 2011.

[10] I. Alnawawi, mutiara Riadhushshalihiin, Bandung, Indonesia: Mizan Pustaka, 2009. 